\title{
Meningioangiomatosis
}

\section{A rare presentation with progressive cortical blindness}

\section{Figure 1 MRI brain}
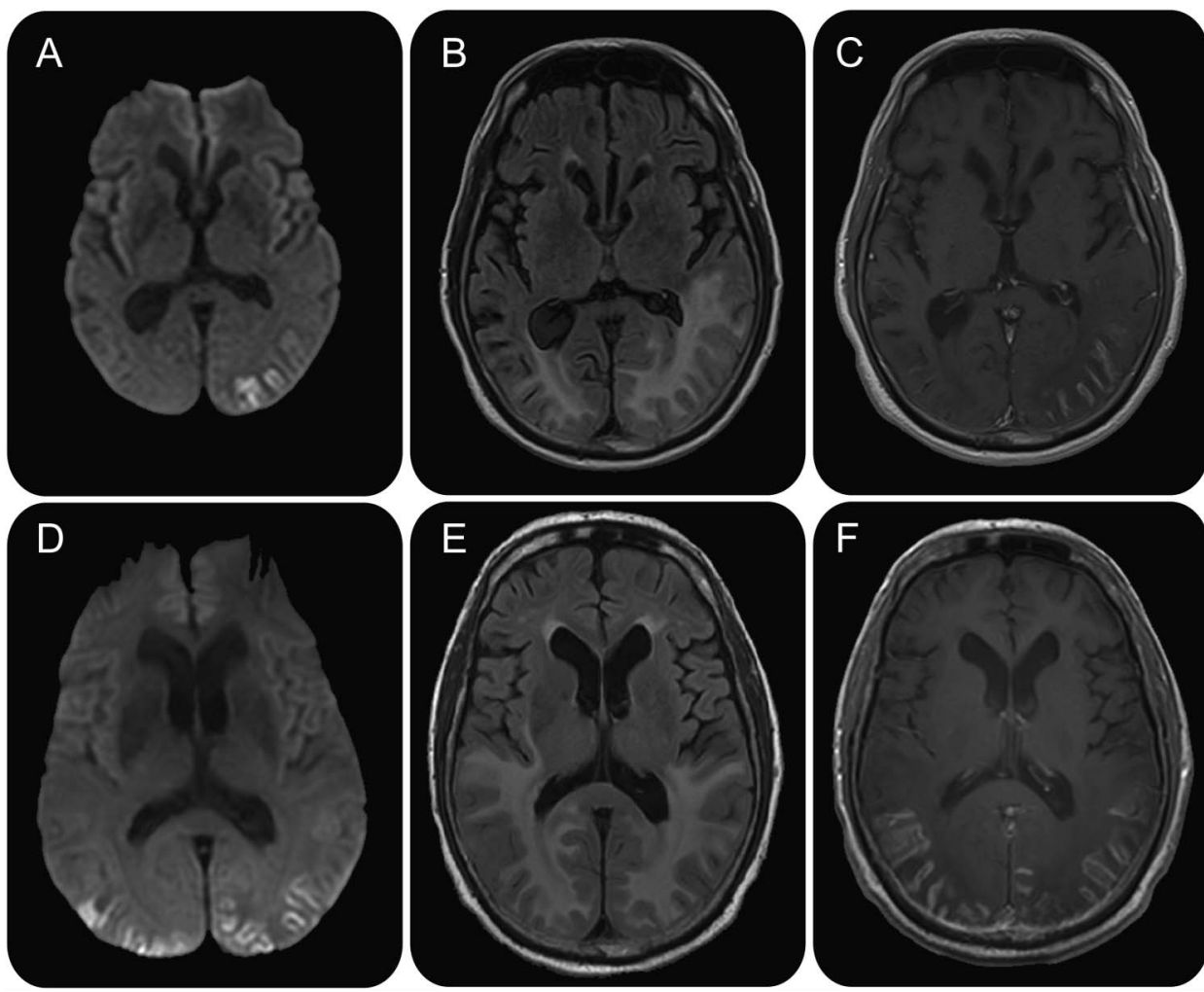

Initial MRI: restricted diffusion (A) with T2 hyperintensities (B) that enhanced with gadolinium (C) in the occipito-parietal lobes. MRI 18 months later: anterior extension of the above abnormalities (D-F).

A 58-year-old man presented with a 6-month history of headaches, progressive left homonymous hemianopia, and right-sided paresthesias. MRI revealed bilateral parietal and occipital enhancing lesions (figure 1, A-C) suggestive of cerebritis or posterior reversible encephalopathy syndrome due to history of hypertension. Worsening vision prompted neuroimaging 18 months later, showing contrast-enhancing cortical lesions in the posterior frontal region; fluid-attenuated inversion recovery abnormalities in the white matter (figure 1, D-F) suggested vasogenic edema and mass effect. Occipital lobe biopsy revealed cortical mesenchymal capillary proliferation typical of meningioangiomatosis (figure 2), a rare benign progressive disorder characterized by cortical vascular proliferation with associated perivascular mesenchymal cell proliferation. ${ }^{1}$ Seizures are the presenting feature in $85 \%$ of sporadic cases; there have been no reports with permanent focal dysfunction ${ }^{2}$ as in this instance.

Akshay Shah, MD, Daniel Korya, MD, Brandon T. Larsen, MD, PhD, Myrka Torres, MD, Kendra Drake, MD, John La Wall, MD

From University Medical Center, University of Arizona, Tucson.

Author contributions: Akshay Shah, MD: primary author, case concept and design. Daniel Korya, MD: coauthor, critical revision of the manuscript for intellectual content. Brandon T. Larsen, MD, PhD: coauthor, critical revision of the manuscript for intellectual content. Myrka Torres, MD: critical revision of the manuscript for important intellectual content and supervision. Kendra Drake, MD: critical revision of the manuscript for important intellectual content and supervision. John La Wall, MD: critical revision of the manuscript for important intellectual content and supervision. 


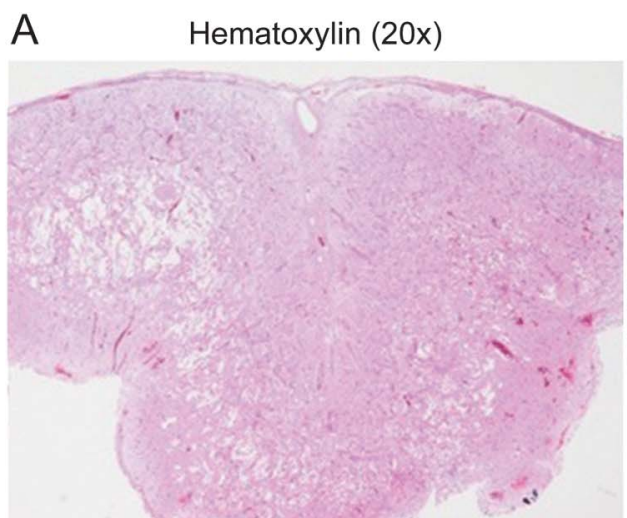

B Vimentin (20x)

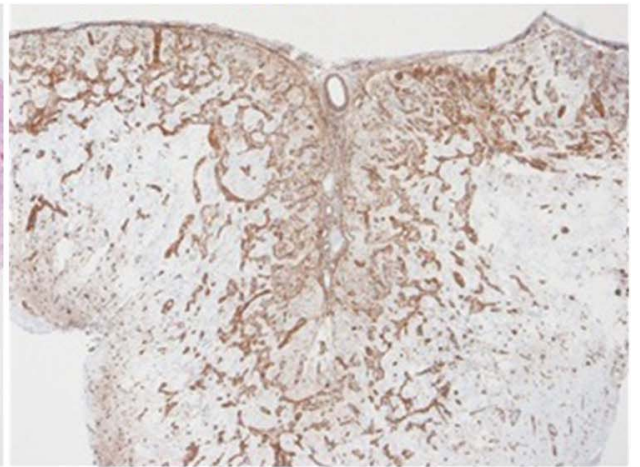

C Hematoxylin and Eosin (200x)

D
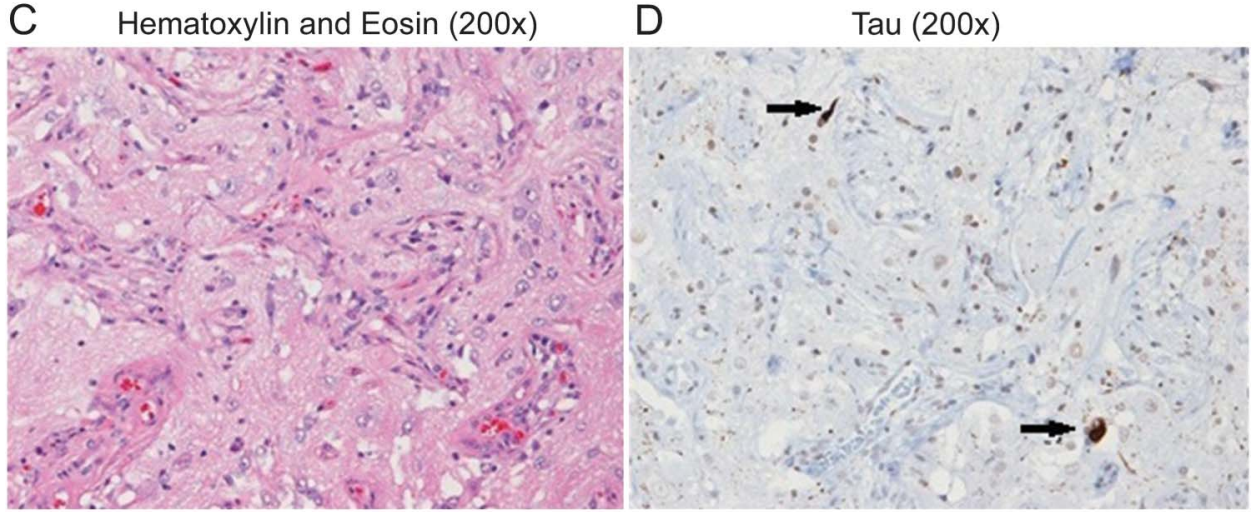

F Neurofilament $(200 x)$

$\mathrm{E}$

CD34 (200x)

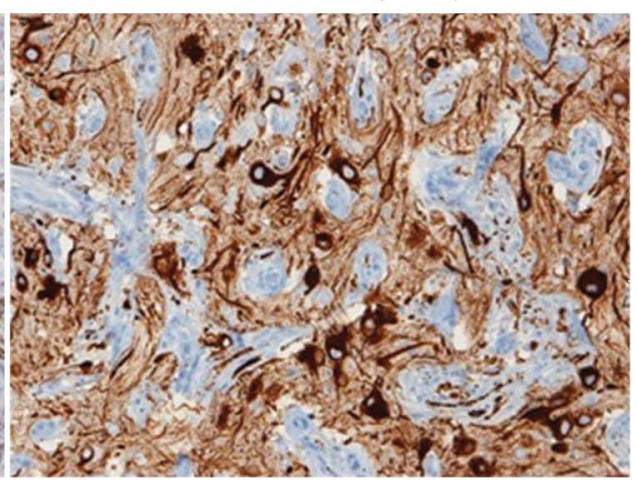

Plaque-like capillary proliferation encroaching the cortex (A) ensheathed by mesenchymal cells (C). Immunohistochemical staining highlighted mesenchymal proliferation (B), granulovacuolar degeneration (D) with neurofibrillary tangles (arrows), proliferating capillaries (E), and entrapped neurons (F).

Study funding: No targeted funding reported.

Disclosure: The authors report no disclosures relevant to the manuscript. Go to Neurology.org for full disclosures.

Correspondence to Dr. Shab: ashab@uph.org

1. Halper J, Scheithauer BW, Okazaki H, Laws ER Jr. Meningio-angiomatosis: a report of six cases with special reference to the occurrence of neurofibrillary tangles. J Neuropathol Exp Neurol 1986;45:426-446.

2. Wiebe S, Munoz DG, Smith S, Lee DH. Meningioangiomatosis: a comprehensive analysis of clinical and laboratory features. Brain 1999;122:709-726. 


\title{
Neurology
}

\section{Meningioangiomatosis: A rare presentation with progressive cortical blindness}

\author{
Akshay Shah, Daniel Korya, Brandon T. Larsen, et al.
}

Neurology 2013;81;511-512

DOI 10.1212/WNL.0b013e31829d8714

This information is current as of July 29, 2013

\section{Updated Information \& Services}

References

Citations

Subspecialty Collections

Permissions \& Licensing

Reprints including high resolution figures, can be found at: http://n.neurology.org/content/81/5/511.full

This article cites 2 articles, 0 of which you can access for free at: http://n.neurology.org/content/81/5/511.full\#ref-list-1

This article has been cited by 2 HighWire-hosted articles: http://n.neurology.org/content/81/5/511.full\#\#otherarticles

This article, along with others on similar topics, appears in the following collection(s):

\section{Arteriovenous malformation}

http://n.neurology.org/cgi/collection/arteriovenous_malformation MRI

http://n.neurology.org/cgi/collection/mri

Secondary headache disorders

http://n.neurology.org/cgi/collection/secondary_headache_disorders Visual loss

http://n.neurology.org/cgi/collection/visual_loss

Information about reproducing this article in parts (figures,tables) or in its entirety can be found online at:

http://www.neurology.org/about/about_the_journal\#permissions

Information about ordering reprints can be found online:

http://n.neurology.org/subscribers/advertise

Neurology ${ }^{\circledR}$ is the official journal of the American Academy of Neurology. Published continuously since 1951, it is now a weekly with 48 issues per year. Copyright () 2013 American Academy of Neurology. All rights reserved. Print ISSN: 0028-3878. Online ISSN: 1526-632X.

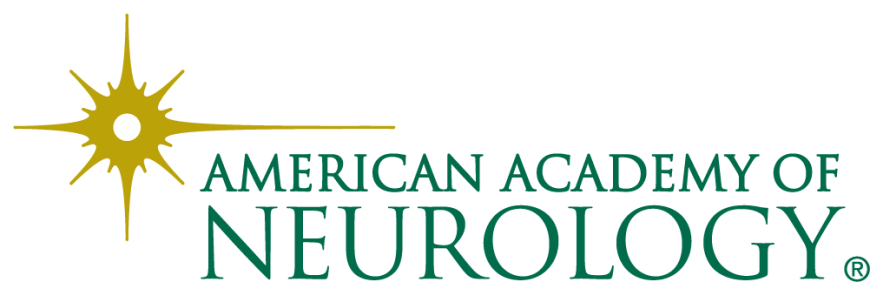

